\title{
PERANCANGAN IKLAN LAYANAN MASYARAKAT PEMANFAATAN SAMPAH PLASTIK
}

\author{
Desi Priani ${ }^{1}$, Susas Rita Loravianti ${ }^{2}$, Syafwandi $^{3}$ \\ 1,2Program Studi Pascasarjana Institut Seni Indonesia Padangpanjang \\ ${ }^{3}$ Program Studi Desain Komunikasi Visual, Universitas Negeri Padang \\ 1 chi.priani1512@gmail.com, ${ }^{2}$ loravianti@ymail.com, ${ }^{3}$ syafwandi1960@gmail.com
}

\begin{abstract}
ABSTRAK
Artikel/penelitian ini bertujuan membahas perancangan iklan layanan masyarakat pemanfaatan sampah plastik. Perancangan iklan layanan masyarakat pemanfaatan sampah plastik ini untuk mengingatkan masyarakat tentang bahaya limbah plastik terhadap lingkungan dan kehidupan manusia. Limbah plastik tidak bisa terurai di dalam tanah. Sampah plastik banyak sekali dihasilkan dari rumah tangga. Untuk itu perlu adanya kreativitas dari masyarakat sebagai upaya pemanfaatan dan pengurangan sampah plastik menjadi barang yang mempunyai manfaat lagi. Perlu adanya strategi kreatif yang berkaitan dengan ide dan konsep iklan layanan masyarakat terhadap pemanfaatan sampah plastik menjadi sebuah pesan yang menarik perhatian masyarakat. Masyarakat adalah target audience (sasaran utama) dari ini perancangan ini. Adapun metode penelitian yang digunakan dalam perancangan iklan layanan masyarakat ini adalah metode penelitian kualitatif. Penulis ingin merancang beberapa media sebagai sarana penyampaian iklan ini seperti spanduk, poster, baju, atau tas kain agar lebih mudah untuk dapat diketahui atau dilihat oleh masyarakat luas khususnya orang tua.
\end{abstract}

Kata Kunci : perancangan, iklan layanan masyarakat, pemanfaatan, sampah plastik, penelitian kualitatif

\begin{abstract}
This article / study aims to discuss the design of public service advertising about the utilization of plastic waste. The design of public service advertising about the utilization of plastic waste to remind the public about the dangers of plastic waste to the environment and human life. Plastic waste can't decompose in the soil. Plastic wastes are generated from households. For that we need the creativity of the community as an effort to utilize and reduce plastic waste into goods that have benefits again. The need for a creative strategy related to the idea and concept of public service advertisements on the utilization of plastic waste into a message that attracts the public's attention. Society is the target audience (main target) of this design. The research method used in the design of public service advertising is a qualitative research method. The author wants to design some media as a means of delivering these ads such as banners, posters, clothes, or cloth bags to make it easier to be known or seen by the wider community, especially parents.
\end{abstract}

Keyword : designing, public service advertising, utilization, plastic waste, qualitative research

\section{PENDAHULUAN}

Hampir setiap orang pasti tidak akan terlepas dari yang namanya bahan plastik dalam aktivitasnya sehari-hari. Ya, memang plastik telah menjadi komponen penting dalam kehidupan modern saat ini dan peranannya telah menggantikan kayu dan logam mengingat 
kelebihan yang dimilikinya antara lain ringan dan kuat, tahan terhadap korosi, transparan dan mudah diwarnai, serta sifat insulasinya yang cukup baik.

Sifat-sifat bahan plastik inilah yang membuatnya sulit tergantikan dengan bahan lainnya untuk berbagai aplikasi khususnya dalam kehidupan sehari-hari mulai dari kemasan makanan, alat-alat rumah tangga, mainan anak, elektronik sampai dengan komponen otomotif. Peningkatan penggunaan bahan plastik ini mengakibatkan peningkatan produksi sampah plastik dari tahun ke tahun. Sebagai gambaran konsumsi plastik di Indonesia mencapai $10 \mathrm{~kg}$ perkapita pertahun, sehingga dapat diprediksikan sebesar itulah sampah plastik yang dihasilkan.

Dengan adanya contoh kasus di atas, penulis ingin membuat Iklan Layanan Masyarakat Pemanfaatan Sampah Plastik. Adapun metode penelitian yang digunakan dalam perancangan ILM ini adalah metode penelitian kualitatif. Menurut Kiriyantono (2007), "Riset kualitatif bertujuan untuk menjelaskan fenomena dengan sedalam-dalamnya melalui pengumpulan data sedalam-dalamnya". Menurut Bodgan dan Taylor (Moleong, 2006), mendefinisikan metodologi kualitatif sebagai "prosedur penelitian yang menghasilkan data deskriptif berupa kata-kata tertulis atau lisan dari orang-orang dan perilaku yang dapat diamati”.

\section{I.1. Iklan}

Dalam buku Pengantar Desain Komunikasi Visual, Kusrianto (2006:298) menyimpulkan "iklan adalah suatu bentuk komunikasi massa komersial yang dirancang untuk mempromosikan pemasaran suatu produk atau jasa, maupun pesan dari suatu lembaga, organisasi, bahkan bisa jua pesan dari seorang kandidat dalam suatu kampanye politik".

\section{I.2. Iklan Layanan Masyarakat}

Secara umum iklan layanan masyarakat adalah iklan yang menyajikan pesan-pesan sosial yang bertujuan untuk membangkitkan kepedulian masyarakat terhadap sejumlah masalah yang harus mereka hadapi, yakni kondisi yang bisa mengancam keselarasan dan kehidupan umum. ILM merupakan salah bentuk pemasaran sosial yang bertujuan untuk mengubah perilaku masyarakat.

Menurut Kotler dan Roberto elemen-elemen utama pemasaran sosial yaitu:

1. Cause - sasaran sosial yang dipercaya agen perubahan untuk dapat memberikan jawaban terhadap suatu permasalahan sosial.

2. Change agent - individu, organisasi atau kelompok yang mencoba mengadakan perubahan sosial dengan cara melakukan suatu kampanye.

3. Target adopter - individu, kelompok atau keseluruhan populasi yang dijadikan sasaran perubahan oleh pemasar sosial.

4. Channels - jalur komunikasi dan distribusi yang digunakan oleh pemasar sosial dalam memasarkan produk sosialnya.

5. Change strategy - petunjuk dan program yang dipakai oleh agen perubahan untuk mengubah sikap dan perilaku kelompok sasaran. 


\section{I.3. Sampah Plastik}

Sampah plastik sangat sulit terurai dalam tanah, membutuhkan waktu bertahun-tahun dan ini akan menimbulkan permasalahan tersendiri dalam penanganannya. Pembuangan di Tempat Pembuangan Akhir (TPA) sampah bukanlah solusi yang cukup bijak dalam pengelolaan sampah plastik ini. Peranan para pemulung dalam mengurangi timbunan sampah plastik patut mendapat apresiasi meskipun ini tidak bisa menghilangkan seratus persen sampah plastik yang ada. Perlu adanya manajemen sampah plastik mulai dari lingkungan terkecil yaitu rumah tangga hingga skala besar meliputi kawasan kota yang dikelola oleh pemerintah kota atau daerah setempat. Untuk memudahkan pengelolaan sampah plastik pada skala rumah tangga, maka perlu adanya pemahaman tentang jenisjenis plastik, kandungan materialnya, hingga dampaknya terhadap lingkungan sehingga diharapkan terbentuk manajemen pengelolaan yang tepat.

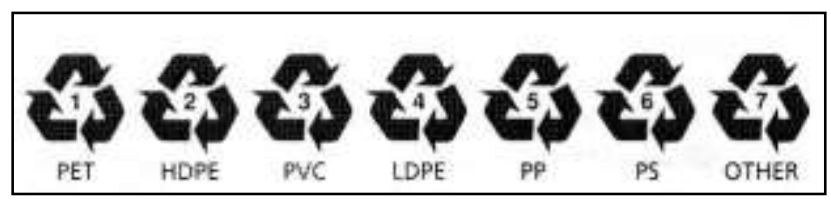

Gambar 1. Simbol recycling plastik yang ada pada produk plastic

Sumber : http://www.olahsampah.com/index.php/manajemen-sampah/36-mengenal-sampah-plastik-danpenanganannya

Beberapa jenis plastik yaitu : · PET atau PETE, atau polyethylene therephthalate. Ringan, murah, dan mudah membuatnya. Penggunaannya terutama pada botol minuman soft drink, tempat makanan yang tahan microwave dan lain-lain. - HDPE (high density polyethylene) Lebih kuat dan rentan terhadap korosi, sedikit sekali resiko penyebaran kimia bila digunakan sebagai wadah makanan, bisa digunakan untuk wadah shampoo, deterjen, kantong sampah. Mudah didaur ulang. · PVC (polyvinyl chloride) Plastik jenis ini memiliki karakteristik fisik yang stabil dan memiliki ketahanan terhadap bahan kimia, cuaca, sifat elektrik dan aliran. Bahan ini paling sulit didaur ulang dan paling sering kita jumpai penggunaannya pada pipa dan konstruksi bangunan. · LDPE (low density polyethylene) Bisa digunakan untuk wadah makanan dan botol-botol yang lebih lembek. • PP (polypropylene) Plastik jenis ini mempunyai sifat tahan terhadap kimia kecuali klorin, bahan bakar dan xylene, mempunyai sifat insulasi listrik yang baik. Bahan ini juga tahan terhadap air mendidih dan sterilisasi dengan uap panas. Aplikasinya pada komponen otomotif, tempat makanan, karpet, dll. · PS (polystyrene) Jenis ini mempunyai kekakuan dan kestabilan dimensi yang baik. Biasanya digunakan untuk wadah makanan sekali pakai, kemasan, mainan, peralatan medis, dll.

\section{I.1. Iklan Layanan Masyarakat}

Iklan di dalam bahasa Melayu diambil dari bahasa Arab, yaitu I'lan atau I'lanun yang secara harfiah berarti "informasi". Iklan adalah suatu sarana menyampaikan informasi dari komunikan baik berupa gagasan, larangan, bujukan, arahan, simbol serta informasi lainnya kepada target audiens dengan tujuan agar target audiens dapat memahami pesan dari iklan tersebut serta tergugah untuk melakukan sesuai dengan pesan yang disampaikan. Iklan layanan masyarakat adalah iklan yang bertujuan untuk menyampaikan informasi dan pesan yang bersifat ajakan kepada khalayak dengan tujuan informasi dan pesan tersebut dapat dimengerti dan turut memikirkan tentang pesan tersebut. 
Iklan layanan masyarakat ini juga bukan untuk mendapatkan keuntungan ekonomi melainkan keuntungan sosial. Widyatama (dalam Pujiyanto 2013:8), keuntungan sosial yang dimaksud adalah menimbulkan kesadaran sosial, sikap, penambahan pengetahuan serta perubahan perilaku masyarakat terhadap masalah yang diiklankan serta mendapatkan citra yang baik di mata masyarakat. Umumnya pesan yang disampaikan dalam iklan layanan masyarakat ini berupa informasi-informasi publik untuk mengguggah khalayak untuk melakukan suatu kebaikan yang sifatnya normatif.

\section{I.2. Sampah Plastik}

Plastik merupakan material yang baru, secara luas dikembangkan dan digunakan sejak abad ke-20, tepatnya pada tahun 1975 diperkenalkan oleh Montgomery Ward, Sears, J.C. Penny, Jodan Marsh dan toko-toko retail besar lainnya (Marpaung, 2009). Plastik berkembang secara luar biasa penggunaannya dari hanya beberapa ratus ton pada tahun 1930-an, menjadi 150 juta ton/tahun pada tahun 1990-an dan 220 juta ton/tahun pada tahun 2005. Saat ini hampir tidak ada supermarket, toko atau warung di Indonesia yang tidak menyediakan kantung plastik (Anonim, 2009).

\section{STUDI LITERATUR}

Iklan Layanan Masyarakat Bahaya Sampah Plastik karya Arry Maulana Syarif, M.Kom dan Asmar Wono Widodo mahasiswa Fakultas Ilmu Komputer Universitas Dian Nuswantoro. Adapun alasan pemilihan tema karena plastik merupakan salah satu bahan yang banyak digunakan untuk pembuatan peralatan rumah tangga, otomotif dan sebagainya. Penggunaan bahan plastik semakin lama semakin meluas karena sifatnya kuat dan tidak mudah rusak oleh pelapukan. Namun demikian plastic memiliki dampak buruk terhadap lingkungan karena sifatnya yang tidak lapuk ketika dibuang sehingga mengurangi efisinsi pembungan sampah. Dan Iklan Layanan Masyarakat akan Bahaya Sampah Plastik bagi kehidupan mempunyai tujuan yang ingin dicapai dari Iklan Layanan Masyarakat diantaranya masyarakat sadar akan bahaya sampah plastik dan mensosialisasikan tentang bahaya sampah plastik yang butuh waktu sangat untuk terurai.

Jurnal iklan layanan masyarakat tentang pengolahan sampah rumah tangga yang ditulis oleh Made Marthana Yusa mahasiswa Teknik Informatika STMIK STIKOM Indonesia ini menggunakan video animasi 2 dimensi model infografik menjelaskan tentang bagaimana pengelolahan sampah yang sangat banyak dihasilkan dari lingkungan rumah tangga khususnya di Denpasar. Dalam iklan layanan masyarakat ini, Made Marthana Yusa mengajak masyarakat agar dapat ikut serta berpartisipasi dalam hal pengelolaan sampah rumah tangganya masing-masing dengan metode pengolahan sampah 3R. Sebelumnya sosialisasi tentang 3R oleh DKP kota Denpasar sudah pernah dilakukan dalam rangka penyuluhan di seluruh Bale Banjar di kota Denpasar dengan media presentasi dan pemberian buku saku tentang profil DKP kota Denpasar, hanya saja masyarakat yang mengikuti jumlahnya terbatas sehingga tidak banyak masyarakat yang mengetahui bagaimana pemanfaatan sampah tersebut. Made memilih media sosialisasi berupa video iklan layanan masyarakat berbasis animasi. Menurut Made kelebihan video animasi dibanding media yang lain adalah dapat menyampaikan informasi/ hal yang rumit menjadi hal yang sederhana sehingga mudah untuk dijelaskan. 


\section{PEMBAHASAN}

Berdasarkan data dan informasi yang telah di peroleh, maka agar tahapan dan proses Iklan Layanan Masyarakat Pemanfaatan Sampah Plastik ini lebih mudah dan sistematis maka di perlukan penyusunan metode, strategi, struktur dalam perancangan yang akan di garap.

\section{III.1. Metode Perancangan}

Untuk memperoleh hasil perancangan Iklan Layanan Masyarakat Pemanfaatan Sampah Plastik yang komunikatif dan efektif, dan mampu mencapai tujuan, maka diperlukan sebuah metode yang baik untuk mewujudkannya. Metode perancangan iklan layanan masyarakat pemanfaatan sampah plastik ini dikelompokkan menjadi empat tahap, yaitu :

1. Tahap Observasi dan Identifikasi Data

Tahap ini meliputi pengumpulan data tentang seluruh aspek yang berkaitan dengan masalah sampah khususnya sampah plastik. Hal ini meliputi seberapa besar sampah plastik yang dihasilkan lingkungan rumah tangga ataupun sekolahan. Kemudian bagaimana sampah-sampah plastik tadi dimanfaatkan.

2. Tahap Analisis (Pembahasan)

Pada tahap ini data-data yang telah didapat, dianalisa kembali dengan menggunakan metode analisis $5 \mathrm{~W}+1 \mathrm{H}$. Hal ini bertujuan agar media yang dirancang dapat berkomunikasi dengan baik kepada audience.

3. Tahap Pembuatan Karya (Art Work)

Tahap ini merupakan tahap akhir apabila semua data dan ide serta konsep dirasa sudah layak untuk diracik menjadi sebuah karya.

\section{III.2. Ruang Lingkup Perancangan}

Agar pembahasan dalam perancangan tidak meluas dan agar tidak mengurangi tujuan yang ingin di capai, maka perlu adanya pembatas ruang lingkup di dalam perancangan Iklan Layanan Masyarakat Pemanfaatan Sampah Plastik. Ruang lingkup perancangan di batasi pada pencarian data seputar kondisi lingkungan masyarakat, sekolahan, dan tempattempat wisata. Kegiatan perancangan nantinya meliputi proses perancangan poster sebagai media utamanya, pemilihan media pendukung dan penyajian yang informatif serta di eksekusi dengan sebaik-baiknya. Target utama dalam perancangan ini adalah para ibu rumah tangga, dimana para target audience yang akan di tuju adalah sebagai berikut:

1. Demografis

Usia :25-50 tahun

Terdiri dari : Ibu Rumah Tangga

Jenis kelamin : Perempuan

2. Geografis

Lokasi sasaran yang dituju dalam perancangan ini adalah kawasan tempat tinggal masyarakat.

3. Pisikografi

Secara target perancangan ini mengarah kepada tempat-tempat para ibu rumah tangga seperti warung-warung dan jalan yang mereka lalui.

\section{III.3. Metode Pengumpulan Data}


1. Data verbal

a) Wawancara

Melakukan wawancara dengan bertanya kepada beberapa sumber, dengan melakukan wawancara yang terstruktur, data yang di peroleh berkaitan dengan informasi seputar sampah plastik yang ada di lingkungan sekitar. Hal-hal yang di wawancarai seperti pengetahuan tentang sampah plastik, pemanfaatan sampah plastik dan kerajinan yang bisa diciptakan dari sampah plastik.

b) Observasi

Observasi yang di lakukan adalah dengan terjun langsung kelapangan mengunjungi rumah para ibu rumah tangga untuk mendapatkan data dan informasi yang di perlukan dalam perancangan ini.

2. Data Visual

a) Dokumentasi

Mencari sumber informasi berupa foto, dokumen dan data tentang Pemanfaatan Sampah Plastik.
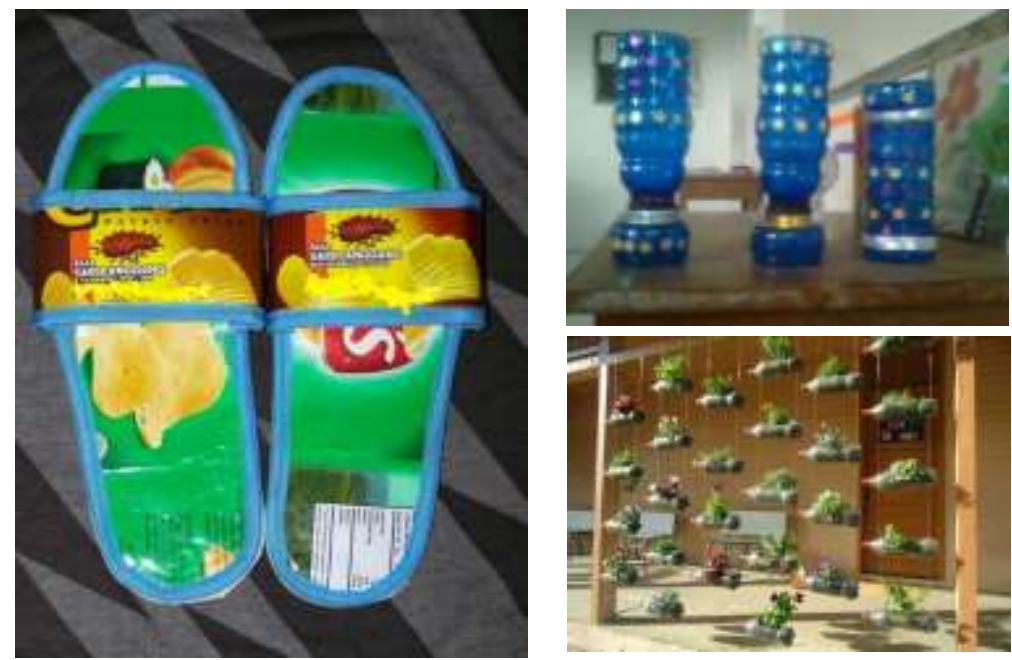

b) Website

Gambar 2. Hasil Karya Pemanfaatan Sampah Plast

Selain dokumentasi, pengambilan data visual serta data lainnya berasal dari data dan visual yang ada di website demi menunjang keperluan perancangan.

3. Analisis Data

Hambatan yang terjadi dalam pencapaian Iklan Layanan Masyarakat ini adalah kurangnya kesandaran dari masyarakat itu sendiri tentang pemanfaatan sampah plastik. Sedangkan faktor yang dapat mendukung agar tercapainya suatu harapan yang dituju adalah melalui adanya penyuluhan dan sosialisasi tentang pentingnya pemanfaatan sampah plastik.

\section{Analisis 5W+1H}

What Iklan Layanan Masyarakat seperti apa yang akan di buat?

Iklan Layanan Masyarakat yang akan dibuat berupa sosialisasi penyuluhan tentang pemanfaatan sampah plastik, sosialisasi ini agar dapat memberikan kesadaran dan menambah wawasan masyarakat, sehingga secara tidak langsung sedikit akan mengurangi limbah sampah plastic 
Who Siapa target sasarannya?

Target sosial dalam ILM ini adalah para ibu rumah tangga.

Why Mengapa perlu adanya sosialisasi penyuluhan?

Mengingat semakin banyaknya sampah plastik yang berasal dari kawasan rumah tangga dan kurangnya pengetahuan para ibu rumah tangga untuk mengolah sampah plastik menjadi hasil karya yang mempunyai nilai multi guna lainnya, maka perlu dirancang Iklan Layanan Masyarakat berupa penyuluhan melalui media Desain Komunikasi Visual.

When Kapan dimulainya?

Perancangan Iklan Layanan Masyarakat Pemanfaatan Sampah Plastik ini dimulai pada saat sekarang dan seterusnya.

Where Dimana akan dilaksanakan?

Sosialisasi ini akan dilaksanakan di Kota Medan dikarenakan Kota tersebut merupakan tempat yang mempunyai banyak timbunan sampah plastik.

How Bagaimana ILM Pemanfaatan Sampah Plastik ini dirancang?

Perancangan ILM Pemanfaatan Sampah Plastik melalui berbagai tahapan, melaui proses berfikir dalam menentukan media yang efektif untuk menarik minat masyarakat untuk pemanfaatan sampah plastik.

\section{III.4. Konsep Kreatif}

Konsep kreatif merupakan sebuah tema, ide pokok atau gagasan unik yang akan diangkat dan dikemas menjadi sebuah produk komunikasi visual. Secara garis besar konsep kreatif merupakan titik awal yang sangat penting untuk menemukan berbagai gagasan baru dan belum pernah ada sebelumnya, agar apa yang akan dikomunikasikan mempunyai sebuah karakteristik atau pembeda.

Untuk Iklan layanan masyarakat Pemanfaatan Sampah Plastik, ada dua ide besar yang akan dijadikan sebagai pijakan dalam perancangannya. Ide tersebut adalah sebagai berikut:

1. Botol Bekas

Botol bekas yang merupakan sampah plastik yang banyak dan sering sekali kita temukan di lingkungan tempat tinggal kita. Kemudian ditambahkan dengan kata "Bukan Sulap" sehingga botol bekas tersebut dimanfaatkan atau diubah menjadi barang yang mempunyai kegunaan.

2. Reuse - Reduce - Recycle

Taqline ini untuk mengingatkan kita, bahwa dengan pemanfaatan sampah plastic yang ada , kita dapat membuat suatu hasil karya kerajinan yang mempunyai manfaat kembali.

Kedua ide besar diatas akan diwujudkan ke dalam bentuk visual yang menarik agar bias menarik perhatian target audience, dan diaplikasikan ke dalam beberapa media publikasi, seperti poster.

\section{III.5. Strategi Kreatif}

Secara umum, strategi kreatif merupakan rangkaian kegiatan untuk merumuskan bentuk, isi, serta strategi penyampaian pesan (verbal dan visual), sebelum masuk ke tahap 
pengerjaan atau eksekusi sebuah produk komunikasi visual. Dalam strategi kreatif, semua hal yang berkaitan dengan ide dan konsep perancangan ILM Pemanfaatan Sampah Plastik, akan diracik menjadi sebuah pesan yang menarik dan menancap ke hati dan benak target audience.

Adapun yang harus ditentukan dalam perancangan ILM Pemanfaatan Sampah Plastik adalah sebagai berikut:

a. Isi Pesan

Pesan dalam ILM ini bertujuan untuk mempersuasi target audience agar paham bagaimana cara memanfaatkan sampah plastik.

b. Bentuk Pesan

1. Pesan Verbal

Pesan Verbal merupakan pesan berupa teks atau kata-kata, yang tujuannya adalah sebagai pendukung yang memperjelas pesan visual. Melalui pesan verbal inilah iklan bisa lebih efektif untuk berkomunikasi dengan target audience agar tujuan iklan dapat tercapai. Pesan pada ILM menyatakan dengan tegas bahwasannya dengan pemanfaatan sampah plastic yang ada kita dapat menciptakan kembali barang yang mempunyai kegunaan.

2. Pesan Visual

Untuk pesan visual ILM Pemanfaatan Sampah Plastik akan ditampilkan visual dengan menggunakan botol bekas, karena banyak kegunaan botol bekas yang dapat menghasilkan barang yang bermanfaaat. Botol bekas yang merupakan sampah plastic yang banyak kita jumpai disekeliling tempat tempat tinggal atau pun tempat-tempat wisata menjadi objek utamanya,kemudian ditambahkan tulisan "BUKAN SULAP" dan dilengkapi kembali dengan hasil karya yang terbuat dari botol plastic tersebut. Hal ini mempunyai maksud bahwa sebuah botol bekas dapat dijadikan sebuah barang yang mempunyai kegunaan baru dengan ide kreatif yang kita punya.

\section{III.6. Media Planning}

Efisiensi penggunaan media dilihat dari sejauh mana media tersebut dapat menjangkau sasaran yang tepat, frekuensi yang dibutuhkan dan durasi penayangan iklan pada media dengan intensitas yang tinggi. Pemilihan media komunikasi yang tepat berdasarkan kekuatan dan kelemahan masing-masing media merupakan faktor penting dalam mendukung keberhasilan periklanan sehingga tujuan periklanan dapat tercapai dan tidak sia-sia. Dalam periklanan, media dapat dikelompokkan menjadi dua bagian, yaitu media utama dan media pendukung.

Dalam perancangan ILM Pemanfaatan Sampah Plastik, media utama yang akan digunakan adalah Poster, sedangkan untuk media pendukung akan digunakan seperti stiker, spanduk,pin dan kalender.

\section{III.7. Strategi Media}

Strategi media merupakan suatu metode yang diterapkan untuk mencapai tujuan media. Dalam strategi media kita mengenal istilah paduan media, yang berarti sebuah pertimbangan pemilihan media yang akan diaplikasikan dalam kegiatan publikasi. Untuk ILM Pemanfaatan Sampah Plastik, media utama yang akan digunakan sebagai sarana promosi adalah poster dan spanduk atau baliho. Media ini dirasa sangat efektif untuk menyampaikan pesan kepada target audience. Sedangkan untuk media pendukung, media publikasi akan dirancang berupa stiker,pin dan kalender. 
Berikut adalah perincian tentang media yang akan dipergunakan dalam Iklan Layanan Masyarakat Pemanfaatan Sampah Plastik :

\section{Media Utama}

Media utama yang akan digunakan adalah Poster. Poster adalah media promosi berupa media cetak. Dari segi ukuran, poster jauh lebih kecil bila dibandingkan dengan baliho. Poster biasanya ditempatkan di ruang publik yang memungkinkan untuk diperhatikan dalam waktu yang cukup lama, seperti di dalam ruangan sebuah gedung, di papan-papan pengumuman instansi dan pada ruang publik lainnya.

Beberapa keunggulan dari media ini antara lain :

- Karena sifatnya yang fleksibel, maka poster memungkinkan untuk ditempel di berbagai ruang publik.

- Kemampuan reproduksinya cukup tinggi.

- Informasi yang ada di dalam poster bisanya lebih akurat dan rinci, sehingga masyarakat dapat menangkap informasi dengan lebih jelas.

- Menarik perhatian, karena poster memungkinkan penciptaan dan eksplorasi desain grafis yang sangat luas.

2. Media Pendukung

Selain media utama, dalam perancangan juga di ikut sertakan media pendukung, tujuannya adalah sebagai sarana untuk mendukung media utama dalam mempromosikan kampanye sosial ini di kota Medan. Di antaranya adalah : brosur dan kalender, selain dari itu dengan adanya media pendukung akan bermanfaat untuk mendukung terciptanya kampanye ini dan juga menjangkau langsung audien yang dituju.

III.7. Pengaplikasian Desain

Pengaplikasian desain adalah desain yang sudah terpilih kemudian akan di tuangkan ke dalam beberapa jenis media seperti :

1. Poster

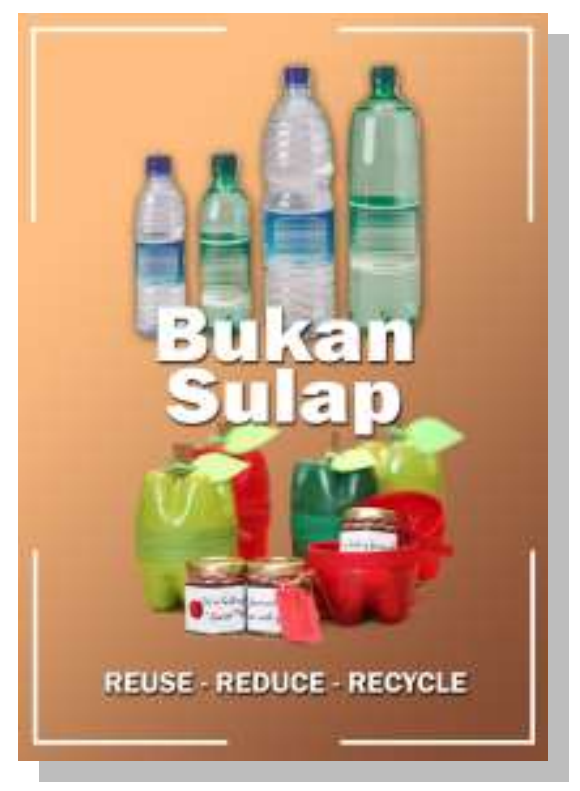

Gambar 3. Desain Poster Sebagai Media Kampanye Sosial Sumber : Desi Priani, 2017 
2. Baju

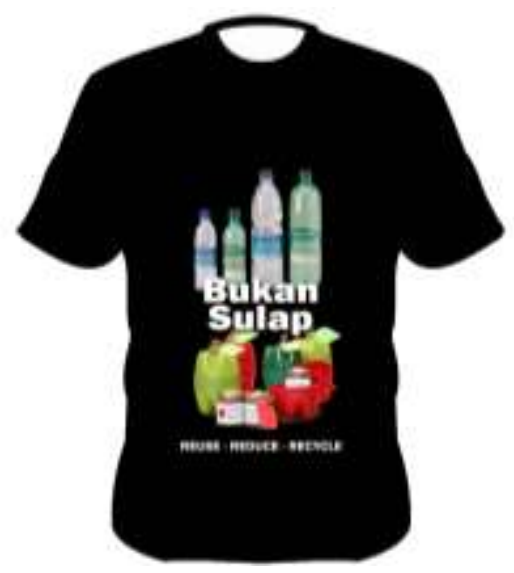

Gambar 4. Desain Baju Sebagai Media Kampanye Sosial Sumber : Desi Priani, 2017

3. Mug

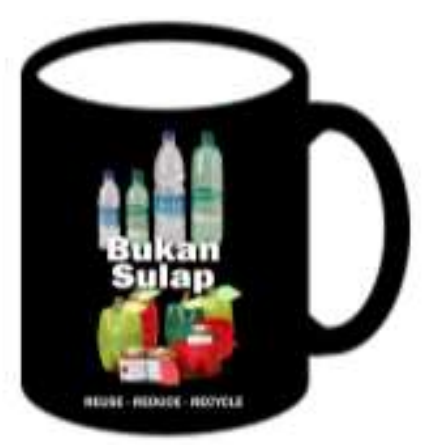

Gambar 5. Desain Mug Sebagai Media Kampanye Sosial Sumber : Desi Priani, 2017

4. Gantungan Kunci

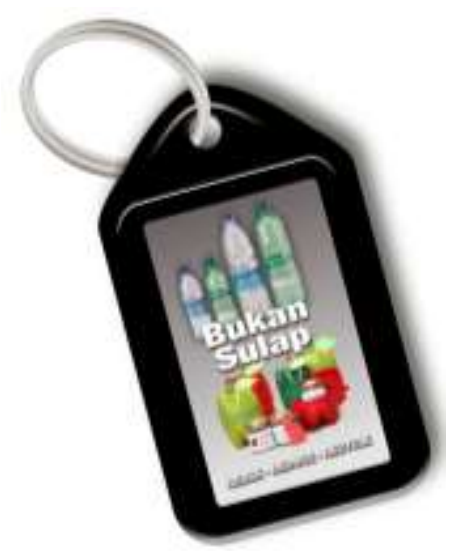

Gambar 6. Desain Gantungan Kunci Sebagai Media Kampanye Sosial Sumber : Desi Priani, 2017 
5. Tas

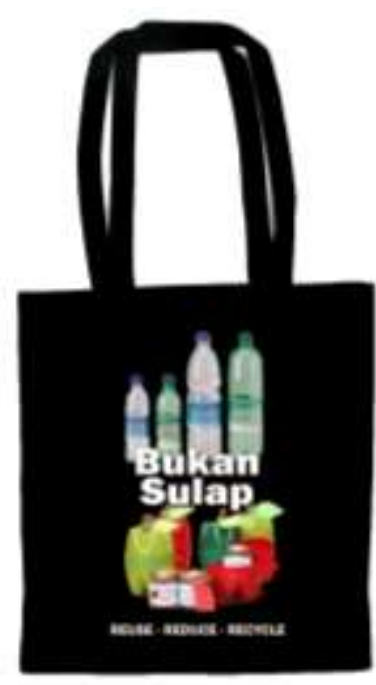

Gambar 7. Desain Tas Sebagai Media Kampanye Sosial Sumber : Desi Priani, 2017

\section{KESIMPULAN}

Berdasarkan hasil data riset dan tindak perilaku masyarakat, perancang dapat menyimpulkan tingkat pertumbuhan penduduk, kurangnya kesadaran masyarakat serta kurangnya masyarakat yang membuang sampah sembarangan.

Harapan yang ingin perancang gapai adalah mengajak para masyarakat khusunya para ibu rumah tangga untuk tanggap dan peduli terhadap sampah plastik, yang kemudian diolah kembali menjadi barang-barang yang sangat bermanfaat.

\section{DAFTAR PUSTAKA}

\section{Buku}

[1] Arsyad, Azhar. 2011. Media Pembelajaran.cetakan ke-15. Jakarta : Rajawalli Pers. Jones, Christophe. 1969. Design Methods.

[2] Kusrianto, Adi. 2006. Pengantar Desain Komunikasi Visual. Yogyakarta: Andi

[3] Migristine, Rinrin. 2007. Pengolahan Sampah Plastik.Titian Ilmu

[4] Sachari, Agus . 2005. Metode Penelitian Budaya Rupa. Jakarta: Erlangga

[5] Supriyono, Rahmat. 2010. Desain Komunikasi Visual Teori dan Aplikasi. Yogyakarta: Andi

[6] Tinarbuko, Sumba. 2009. Semiotika Komunikasi Visual. Yogyakarta: Andi

\section{Sumber Online/ internet:}

[7] http://olahsampah.com/index.php/manajemen-sampah/36-mengenal-sampah-plastikdan-penanganannya 